\title{
Study on the Course System Modular Feasibility of the "Internet + Education" Product Design
}

\author{
Dan Chang ${ }^{1, a}$ \\ ${ }^{1}$ Changchun Sci-Tech University, Changchun, Jilin, China, 130600 \\ ${ }^{a}$ email
}

Keywords: Course System, Modular Feasibility, "Internet + Education", Product Design

\begin{abstract}
In this paper, the "Internet + Education" curriculum system module concept as the main point of entry, based on product design professional development status, the "Internet + education" curriculum system into the teaching classroom. Product design professional "Internet + education" curriculum system module can effectively lead the teaching, to promote the enthusiasm of students to learn to promote the integration of traditional courses and the Internet, to create new personnel training mechanism to become all sectors of the training model, and with the market adapt to society.
\end{abstract}

\section{Introduction}

Internet + education include all aspects of education. Internet + classroom, can change the school classroom education organization model; Internet + teaching, you can change the teaching methods, means; Internet + learning, directly change the student's learning initiative; Internet + evaluation, so that the classroom and society directly related. (1) Internet + Product Design Course. Internet + course, can form a massive network of courses, online courses, so that schools change the organization of teaching, management, students cannot complete the corresponding education, that is, people say "MOOC." The use of "MOOC", for online learning, on the one hand can let all students can directly hear the senior experts, professors taught by the course, on the other hand also to facilitate students to learn according to their own progress. Internet + Product Design Teaching Means. Internet + art education means, is based on the characteristics of design education, through the Internet, the formation of a new network teaching system. For the design education, although long ago to abandon the traditional teaching methods such as blackboard, and the use of modern multimedia technology, but in the Internet + era, courseware, video is mainly used by teachers alone, did not form a resource sharing, teaching content or to the main course teachers. The emergence of Internet + has changed the source of teacher teaching resources, providing more teaching support means. The same knowledge points using the same teacher's "micro-class", both to strengthen the ability of students to self-study, but also unified the teaching content for the basic design of art and design courses to provide the conditions, but also made a request. The main meaning of "Flipped Class Model" is that students become the main body of teaching, teachers through the Internet in advance to arrange teaching content, students through the Internet to use high-quality teaching resources to learn, learning problems arising from teachers to solve doubts. The use of flip classroom to achieve the Internet + learning, the most important advantage is to change the concept of learning and learning methods. Students take the initiative to seek knowledge on the Internet, find their most interesting teaching points and the most need to solve the doubts, learning becomes interesting and active. Turn the classroom to change the student's attitude to learning, but also changed the teacher's teaching ideas. In the existing teaching system, the teacher's evaluation of the students mainly through classroom operations, examinations, etc. to complete the evaluation of the main body is the teacher, evaluation stay at the school level. The emergence of Internet + education, change the way of teaching evaluation, teachers can evaluate students, students can also evaluate teachers, at the same time, teachers, students can give the education sector scoring, the education sector through the network can monitor teaching; school teaching results can be released through the network appeared in front of the public, enterprises through the network to understand the 
school's teaching level. Students' professional ability, teacher's information organization, integration ability, student, teacher teaching achievement transformation, teachers and students through the Internet to obtain the degree of resource sharing and so on will become a common indicator of evaluation teaching.

\section{Product Design Basic Curriculum System Modular Settings under the Internet + Era}

From the current situation, many art institutions still adhering to the traditional design courses to sketch, color, three constitute the main content of the main content of teaching. Among them, the sketch, the color of the teaching method is mainly painting the object of the sketch, students' geometric structure for the observation, realistic evaluation criteria. This method is very easy for students to indulge in the object to reproduce the imitation, and forget the designer as a subjective reconstruction, refining the reconstruction of the design elements of the visual treatment, so that students lack a variety of aesthetic ability, lack of design services for others should show objective and reasonable. (2) Because some teachers are from the traditional painting professional transfer over the teaching, the lack of understanding of the design, design sketches, design color teaching content and the late design courses cannot afford, did not enable students to learn to observe the ability to design thinking ability. As the ancestor of design education, Bauhaus's three major composition from the introduction of Chinese art education, has been occupied by the design of the basic focus of the course, the design of educational philosophy emphasizes the product design courses should be more concerned about the cultivation of aesthetic cultivation, emphasizing creative thinking, observation ability and design expressive training, but in the implementation of Chinese art institutions, only pay attention to the form of composition exercises, and lost the spirit of the basic design practice, resulting in a large number of students out of school, almost all the same knowledge, learning are the same thing, the lack of their own characteristics. (3) professional basic curriculum teaching system modular settings, mainly refers to the professional design courses based on the design basis of the demand, the professional basic course by design thinking training, performance training, creative development training in three directions for curriculum. Visual training, the form of basic training is the students of things to observe the ability to reorganize the ability of students from the traditional thinking of the liberation, learn to use the design language to think about the problem; modeling elements, design color solution is the performance of students on the performance , in the Internet + era, not necessarily use the traditional pen and paper, electronic information technology should also be integrated into the color, the expression of elements; dynamic graphics creativity, creative thinking training is to enable students from the traditional two-dimensional to three-dimensional, four-dimensional direction, combined with new media, new technology, to achieve the design of new creative direction. The three modules of the basic curriculum design, to solve the design of specialized courses required students' professional ability, as the design of the first year of general education class, in order to better professional ability to support.

\section{Product Design Professional Curriculum System Planning}

Today's education in the era of inheritance at the same time, innovation is the goal of the curriculum system. Innovative education, innovative curriculum is an important part of curriculum development. Personalized curriculum, the new knowledge system, innovative thinking training and training, the social market demand for talent goals can be proportional. Today's education needs such a talent, which is a special educational education in the form of education. "Internet + education" can effectively drive teaching, to stimulate students to learn the initiative, so that students start from the hobbies, and ultimately into knowledge and skills. All into the Internet platform, so that the first time in the college to master the first information, master the updated design techniques and knowledge system, enough to accurately grasp the development of the industry, professional skills and business standards have a high standard and understanding. And according to market demand create innovative thinking training courses, training students' 
awareness of innovation. "Internet + " curriculum system reform is worth studying, the product design profession, this is a large curriculum system changes and breakthroughs, but also on the new education bold innovation and try. Module design and planning Want to better implementation and application, but also need to develop a more detailed product design professional "Internet + education" curriculum system module system and curriculum content settings. Grasp the "Internet +" curriculum system module to guide students to self-learning, bid farewell to the previous dependent teaching, improve the teacher system, which are in the future research needs more in-depth solution.

\section{Product Design Basic Course Teaching Methods Modular under the Internet + Times}

Internet + Era under the product design education, including the Internet + course, the Internet + teaching methods, the Internet + learning, the Internet + evaluation, how to use the Internet + technology to form the basic curriculum of design modular teaching, need to find an effective way. From the students to the teacher, from the beginning of the course to the job commentary, from the teacher to post-evaluation, network cloud platform is an important tool to achieve modular teaching. Cloud platform provides the basic content of the product design course module. Teaching cloud platform refers to the use of "cloud computing", the school and teachers gathered to the "cloud", the use of cloud teaching services, to build personalized teaching information environment, to promote students to take the initiative to support teachers to support effective teaching. The emergence of the cloud platform, but also to make the placement of students becomes unified. All teachers are required by the platform requirements for the operation, there will not be part of the class operation is too large, part of the class operation is too small, modular operation is the design of basic courses teaching one of the important content. The cloud platform provides an interactive module for the basic course of product design. Teaching cloud platform for teachers and students provide a good place for interactive exchanges. Students can learn the problem feedback to the teaching cloud platform, the teacher can be doubts Q \& A knowledge displayed in the cloud platform, the formation of teaching $Q \& A$ system. The formation of this system will enable students to see where the basic course of the design is difficult, where the focus is, where the problem is most, so that students from the course system to find their current position, the basic curriculum set a clear Understand, help students to learn. Cloud platform provides the product design basic course evaluation module. Product design basic course teaching evaluation, in the original teaching mode mainly rely on teachers to complete, and the use of cloud platform, so that teaching is no longer a single school teaching, society, enterprises will become a part of the teaching evaluation system. The specific approach is: the teaching evaluation is divided into three modules, teacher evaluation, expert evaluation, business evaluation. Students to complete the work submitted to the cloud platform, become public information, teacher evaluation is also completed on the cloud platform. At the same time, the school hired some industry experts, corporate executives for the appointment of teachers, and professional teachers to evaluate student work. The three modules each account for $33 \%$ of the total score. This evaluation system allows students to better understand the needs of the industry, laying a good foundation for the design of professional courses.

\section{Product Design Basic Course Teaching Terminal Flattening Under the Internet + Times}

Product design basic course modular teaching reform, to achieve the teaching terminal flattening from the following two aspects: teaching resources information. So that the teaching knowledge into a "micro-class", MOOC, into electronic information; teaching evaluation, teaching interaction into a network of teachers and students. Students in the classroom, according to the teacher's guide, the use of mobile phones, flat-panel scanning two-dimensional code, into the teaching cloud platform in the knowledge link, active learning; and then submit the job into the public platform, accept teachers, experts, business evaluation. Teaching means electronic. In the completion of the design process, you can no longer use the traditional approach, and switch to flat and other new tools. Such as the design of color courses, do learn from the color practice, you can first digital 
photography, the formation of color photos, and then through the digital mosaic, the formation of color blocks, and then through the color analysis, the formation of color ratio data, complete color matching program. Do not use the traditional way to draw mosaic, practice time greatly saved, teaching effect is greatly improved.

\section{Conclusion}

In short, in the Internet + era, the basic education of design can no longer be self-proclaimed, but to boldly reform, the use of online education platform, combined with the characteristics of art and design, the formation of basic design and education system module, change the teaching methods, the formation of teaching content, teaching evaluation module, thus forming a new product design education model.

\section{Acknowledgements}

Fund Project: Jilin Province, education science "thirteen five" planning general issues, "'" Internet + education "under the background of the university product design professional curriculum system modular construction and practice research", subject approval number GH170979.

\section{References}

[1] Zhang Jian. Art and Design Basic Education Innovation and Development - Comment on "Design Basis" [J]. Journal of China Education 2017 (08)

[2] Zhang Jiong. Art design basic course teaching problems and countermeasures [J]. Art Education Research. 2017 (04)

[3] Guo Jing. The application of color "simplification" in the basic teaching of art design in higher vocational education[J]. Drama House. 2017 (06)

[4] Hong Ying, Luo Pingjia, Ning Fang. Under the concept of general education of art design basic education[J]. Education and occupation. 2012 (29)

[5] Zheng Liwei. Root depth to Ye Mao - re-examine the reform of art and design basic courses [J].Journal of Jiyuan Vocational and Technical College. 2011 (03)

[6] Wu Di. Conversion perspective to see the whole - on the overall relationship between the basic design of art and design [J]. Fine Arts. 2006 (03)

[7] Zheng Kui. On the orientation and design of the basic course of art design [J]. Fine Arts. 2013 (02) 